\title{
DIFFERENT APPROACHES OF CLIENTS AND CONSULTANTS TO CONTRACTORS' QUALIFICATION AND SELECTION
}

\author{
Mehmedali Egemen, Abdulrezak N. Mohamed \\ Dept of Civil Engineering, Eastern Mediterranean University, Gazimagusa, Mersin 10, Turkey \\ E-mail: mehmedali.egemen@emu.edu.tr
}

Received 19 Apr 2005; accepted 29 July 2005

\begin{abstract}
Nowadays, clients are the dominant groups in almost all types of industries. However, the construction industry is unique and consultants, as representatives of clients, are very important figures in this industry as well. By presenting survey findings of 91 clients and 50 consultants, this study reveals clients' and consultants' differing expectations of contracting organisations during contractor qualification and selection. The study has clearly confirmed the fact that consultants' perspectives are rather different and their contractors' expectations of their clients vary very significantly from the clients themselves. Furthermore, significantly different results were found even among different types of consultants and different categories of clients. Moreover, this study showed that both clients and consultants had high willingness to continue working with the same contractor in possible future works assuming they are satisfied with the previous works. The criteria, which contribute to achieving full client and/or consultant satisfaction and hence lead to possible repetitive works are identified and the results showed the existence of significant difference between clients and consultants perspectives regarding this issue as well. The framework presented within this paper aims to help the contracting organisations to compare and recognise the different approaches and perceptions of both clients and consultants during contractor qualification and selection processes. The contracting organisations in the related sectors will be able to use the framework provided within this study to recognise the overall demand in a more complete and better manner and hence formulate or modify strategies accordingly.
\end{abstract}

Keywords: contractor qualification, contractor selection, client's expectations, consultant's expectations, client's satisfaction, repetitive works.

\section{Introduction}

The process of construction project implementation produces neither a pure product nor a pure service but may be considered a hybrid process consisting of both product and service components [1]. Traditionally, the evaluation of performance in construction generally focuses on three major performance elements which are completing the project in time, within budget and the required quality standards. 'Soft' performance criteria such as customer's satisfaction, is still at an early evolutionary stage in construction industry [2]. However, today's clients are more aware. Hence, the role played by today's construction clients is higher than it has ever been before. Although many organisations in construction market believe that a high-quality work and a history of success are enough for surviving in this industry, actually it is not anymore. Nowadays, the 'value' concept is involved in construction markets and the clients in the construction industry expect the best possible 'value' of contractors. They started to commission work to the firms giving a high attention to all their needs and expectations. AlMomani [3] found that the lack of attention devoted to the owner's satisfaction undoubtedly contributed to a poor performance and also that current technical failures are minor compared to the existence of very high client dissatisfactions. The study by Maloney [1] came to a conclusion that a contractor must have a detailed understanding of the customer's expectations and be able to satisfy those expectations.

Construction has always been known as 'unique' compared to other sectors. It should be obvious to everyone that there exist fundamental and major differences between consumer markets and the construction market. Probably the most important difference lies in the client himself. In general consumer sectors, the customer who will actually buy the product with his money is usually the only one, whose needs, wants and demands need to be considered. However, in the unique construction industry, in addition to clients, consultants as representatives of clients will almost always have very important roles to play as well. Their expectations on behalf of their clients deserve to be given a high emphasis during any kind of strategy formulation by the contracting organisations. Considering the fact that consultants are 
experts of this issue, their perspective regarding contractor qualification and selection may be rather different than ordinary clients' with possibly no background about construction process at all. A strategy based on input, which does not take consultant's perspective into consideration, will not be complete and hence may not serve the purpose effectively.

It is also a known fact that contractors in the construction industry usually need to build long-term relationships with some of their customers. Relationship marketing is a concept for developing long-term and sustained contact with clients so that their needs can be targeted and satisfied in return for client loyalty [4]. Actually, relationship marketing or repetitive works concept is very suitable for applying in construction industry by its nature. In order to do repetitive works, the contractors should understand the clients' needs and expectations, act accordingly, satisfy, develop close relationships with them and then finally look for repeat business in the long run. Hence, if the client is not fully satisfied, this will probably exclude the contractor from possible future work opportunities with the same client.

The main objective of this research was to reveal different approaches and perceptions of clients and consultants regarding contractor qualification and selection processes. For this purpose, data were collected from both private building construction clients and consultant firms (on behalf of their clients) on their perceptions of a set of criteria related to their expectations from the contractor firms in a specified market. Comparisons were made to reveal the differences. Moreover, these clients' and consultants' approaches to 'the repetitive works concept' and their perception of a specifically defined set of criteria regarding this issue were determined and compared.

\section{Review of criteria for contractor qualification and selection}

Considering the crucial importance of the topic for the construction industry, many researchers have already highlighted client's criteria for contractor qualification and selection processes under varying circumstances of different construction markets. However, the consultant firms' perspective regarding this issue was dealt with only in very few studies. Considering the role of consulting organisations during contractor qualification and selection process, it is obvious that there exists a definite need for a more detailed investigation into this issue.

Hatush and Skitmore [5] found that the most common criteria considered by procurers during prequalification are related to financial soundness, technical ability, management capability, health and safety performance of contractors. The prequalification criteria to be included in the quantitative model for selecting contractors are identified by Holt et al [6]. A methodology for assessing and evaluating contractor data for the purpose of prequalification and bid evaluation is prepared by Hatush and Skitmore [7]. Hatush and Skitmore [8] discuss a systematic multi-criteria decision analysis technique for contractor selection and bid evaluation based on the utility theory. Jennings and Holt [9] approaches the issue from another perspective and discusses not clients' but contractors' viewpoints on prequalification. An investigation of the decision criteria used by client and consultant organisations during contractor prequalification in the $\mathrm{UK}$ is done by $\mathrm{Ng}$ and Skitmore [10]. A framework, which evaluates bids of construction contractors in Saudi Arabia was developed by Alsugair [11]. Ng et al [12] conducted an empirical survey in the UK and investigated the nature of divergencies of the perceived importance of individual prequalification criteria by different groups of prequalifiers. Wong et al [13] identified factors which are used by the clients in contractor selection process. Palaneeswaran and Kumaraswamy [14] proposed another model for construction contractor prequalification process. Maloney [1] examines the relationship between the criteria used by customers in choosing suppliers and factors deriving satisfaction.

The findings of these studies show that the behaviour of clients in different sectors of construction market has rather high variations. Also, consultants' perspective regarding this issue was not assigned the emphasis it deserves in these studies. Furthermore, the perspectives of clients and consultants regarding repetitive works concept were not included at all.

Therefore, a specific study dealing with only the private building construction market in detail and also presenting a comprehensive and combined approach of both the clients and the consultants to this issue would be valuable.

\section{Data collection}

Two interrelated and structured questionnaires, copies of which can be obtained from the first writer, were employed to survey the clients and the consultants in the interviews. The questionnaires consisted of two main sections. The first section was designed to uncover the perspective of clients regarding contractor qualification and selection processes. Hence, it was related to clients' general expectations of the potential contracting organisations. On the other hand, the second section was specifically related to the clients' approach to the concept of doing possible repetitive works with the same contracting organisation in the future. The respondents were asked for their perception of importance attached to the listed criteria. The responses were analysed with respect to the two specified main sections separately. The consultant's questionnaire consisted of the same two sections and the factors as the clients', with only very minor modifications wherever required. The consultant firms were asked to reflect their perspective and assign the appropriate importance to the listed factors on behalf of their clients or potential clients. 
The respondents included in this research were all from private building construction sector in Northern Cyprus construction market. The research sample has been drawn mainly from:

i) the private clients, who had a recent building construction project completed or those who had more than one building project completed in the last 10 years. It was made sure that the responding clients have the relevant knowledge and experience to accurately answer the questionnaire.

ii) the consultants (architects or engineers), who have been working in the market, as representatives of various private building construction clients, for at least 3 years. Descriptive statistics about the client and consultant respondents are summarised in Table 1. The basis of the questionnaires was formed by combining the extensive literature search with the preliminary consultation results, which were obtained from experts in the Northern Cyprus construction market. A pilot study was done, in which participants were asked to comment on the relevance, order and length of the questionnaires. After incorporating all the required modifications according to the inputs obtained in the pilot study, the final version of the questionnaires was reached.

Table 1. Characteristics of client and consultant respondents

\begin{tabular}{|c|c|c|c|}
\hline Variable & Category 1 & Category 2 & Category 3 \\
\hline Type of client & $\begin{array}{l}\text { Villa clients } \\
\text { (34\%) }\end{array}$ & $\begin{array}{l}\text { Apartment } \\
\text { clients } \\
(35 \%)\end{array}$ & $\begin{array}{c}\text { Commercial } \\
\text { building } \\
\text { clients } \\
(31 \%)\end{array}$ \\
\hline Type of consultant & $\begin{array}{c}\text { Engineer } \\
(52 \%)\end{array}$ & $\begin{array}{c}\text { Architect } \\
(48 \%)\end{array}$ & - \\
\hline $\begin{array}{l}\text { Experience of } \\
\text { consultant in building } \\
\text { construction market } \\
\text { (years) }\end{array}$ & $\begin{array}{c}3-5 \\
(32 \%)\end{array}$ & $\begin{array}{c}6-10 \\
(38 \%)\end{array}$ & $\begin{array}{c}>10 \\
(30 \%)\end{array}$ \\
\hline
\end{tabular}

Respondents, who were informed about the overall objectives of the survey at the beginning, included a total of 91 private building construction clients and 50 consultant firms. Face-to-face interviews method was used in data collection in order to prevent any misinterpretation of the questionnaire questions.

\section{Data analysis}

Relative index (RI) technique was used in data analysis. It has been widely used in construction research for measuring attitude with respect to surveyed variables $[9,13,15,16]$. An ordinal scale was used for measurement purposes. The respondents were requested to assign the level of importance from 1 to 5 for each criterion, 1 being 'the least importance', 3 being 'moderate importance' and 5 being 'the most important'. Data from the questionnaires were extracted to determine weightings of all the factors included. The magnitude of RI was calculated for all the listed criteria via the formula:

$$
R I=\frac{\text { Sum of Point Score }}{\left(M^{*} \text { SampleSize }\right)}
$$

where $\mathrm{M}$ represents the maximum possible scale value ( 5 in this case). Therefore, this yielded an index range from 0,2 to 1 , where 1 represented 'the maximum possible importance' and 0,2 represented the 'minimum possible importance'. Then, the variables were rank ordered based on RI, for each of the two main sections in both of the questionnaires.

In an effort to compare the results found for clients and consultants and reveal the possible existing major differences, Spearman Rank Correlation Coefficient test was performed on the pairs of ranks, obtained for the two different parties of respondents in order to define the correlation between them. Hence the differences in perspectives of clients and consultants regarding this issue would be identified. Moreover, in an effort to distinguish among different groups available in clients or consultants population, it was necessary to select a collection of variables that measure characteristics on which the groups are expected to differ. Therefore, different subgroups in both the clients and the consultants samples were identified and analysed separately as well.

\section{Findings and discussions}

There were two main sections in the questionnaires. The first sections of both the client and the consultant questionnaires were designed to uncover the overall perspectives of the respondents regarding contractor qualification and selection. The major possible criteria or expectations of the responding parties from contractor firms were taken into consideration in this section. A summary of 'Relative Indices' and Ranks derived from the responses of 91 clients and 50 consultant firms are presented in Table 2.

Average RI values presented in Table 2 show that consultants lend a little more overall emphasis on the specified factors than clients give them credit for. When the rankings of factors are investigated in detail, it is obvious that there are very major differences among factor rankings of the two different types of respondents. Actually, it can be said that there are very few similarities between the specified groups' approaches. S.R.C.C. test showed a low correlation coefficient of 0,47 at $5 \%$ significance level.

When the scores and rankings are investigated in detail, it is obvious that both the clients and the consultants place extremely high emphasis on the price offered. Although it has been known that more clients are trying to achieve the best value instead of the lowest price in recent years, price was still definitely the most important factor in Northern Cyprus private building construction market. Both overall experience of the contractor firm and specific experience in similar projects also emerged as factors with high importance for both types 
of respondents. 'The image and identity of the firm' was given the third highest score by the clients, which was an interesting finding. Additionally, 'the contractor being a sectoral brand in the market' received a quite high score from the client respondents. These findings are significant indications that the contractor firms should spend more effort for promotional activities. Presenting the company's distinctive features in the language of clients seems to be a significant process for contracting organisations. On the other hand, it was interesting to see the consultants lending rather less emphasis on these two factors than the clients. 'Place of the project' was assigned a high score by the clients although consultants' perspective on this factor was very different. This finding may have significance for house builders, where place is chosen by the contracting organisation. 'Maximum financial capacity' and 'availability of highly qualified technical staff' had much higher importance indices and ranks assigned by the consultants. The approach of most of the clients towards technical factors like 'project monitoring', 'proposed construction methods' or 'workload of the contractor' was not surprising and the clients obviously did not place much emphasis on these factors. On the other hand, consultants definitely placed much more emphasis on these factors. Lastly, it is apparent that 'health and safety on the site' is not a major concern from client's perspective at all. Although consultants assigned a relatively higher score for this factor, it was still one of the lowest in the priority rankings for consultant firms as well.

Average RI values presented in Table 3 for the three different subgroups of clients shows that commercial and villa-type building clients lend more overall significance on the specified factors than apartment type building clients. S.R.C.C. test showed significant correlation to exist among groups. When the factors are investigated separately in detail, it can be observed that apartmenttype clients seem to place much less emphasis on the image and identity of the firm', 'the contractor firm being a sectoral brand' and 'product's place' while they assigned higher rankings to 'previous experience with similar projects' and ' highly qualified technical staff.' Of specific interest, last three factors in the rankings consisted of the same factors and they had very low scores independent of the type of construction project. Considering that there exist many contractor firms on the market, which specialise in certain types of building projects, these specific findings will provide valuable input for them.

The relative indices and ranks for the subgroups available in the consultant sample are presented in Tables 4 and 5 to observe any possible behaviour difference and reveal the approaches of different categories of consultants to their needs and expectations on behalf of their clients. Average RI values presented in Table 4 are very close to each other, which is an indication that 'engineers' and 'architects' lend similar overall emphasis

Table 2. Clients' versus consultants' criteria in contractor qualification and selection a

\begin{tabular}{|c|c|c|c|c|}
\hline \multirow[t]{2}{*}{ Type of respondent } & \multicolumn{2}{|c|}{ Clients } & \multicolumn{2}{|c|}{ Consultants } \\
\hline & RI & Rank & RI & Rank \\
\hline Price that the contractor firm offers & 0,952 & 1 & 0,952 & 1 \\
\hline No of years the contractor firm has been doing work in the market & 0,919 & 2 & 0,900 & 2 \\
\hline The image and identity of the contractor firm in the market & 0,796 & 3 & 0,676 & 10 \\
\hline Availability of previous experience with similar projects & 0,791 & 4 & 0,752 & 7 \\
\hline The product's place if chosen by the contractor & 0,703 & 5 & 0,528 & 14 \\
\hline Availability of highly qualified technical staff in the contractor firm & 0,684 & 6 & 0,880 & 3 \\
\hline References about the contractor & 0,596 & 7 & 0,640 & 12 \\
\hline Previous records of claims and disputes & 0,587 & 8 & 0,688 & 9 \\
\hline The contractor firm being a sectoral brand in the market & 0,578 & 9 & 0,464 & 17 \\
\hline Maximum financial capacity & 0,571 & 10 & 0,876 & 4 \\
\hline Warranty conditions the contractor firm offers & 0,563 & 11 & 0,468 & 15,5 \\
\hline Type of plant and equipment available and suitability of the equipment & 0,545 & 12 & 0,756 & 6 \\
\hline Availability of highly qualified managerial staff in the contractor firm & 0,534 & 13 & 0,792 & 5 \\
\hline Contractor's familiarity with local suppliers, labour, subcontractors etc & 0,468 & 14 & 0,388 & 18 \\
\hline Type of project control, monitoring process and cost control & 0,455 & 15 & 0,672 & 11 \\
\hline Proposed construction method & 0,371 & 16 & 0,712 & 8 \\
\hline Current workload of the contractor & 0,356 & 17 & 0,600 & 13 \\
\hline The contractor's approach to health and safety on the site & 0,336 & 18 & 0,468 & 15,5 \\
\hline Average relative index & 0,600 & & 0,678 & \\
\hline
\end{tabular}

a Spearman Rank Correlation Coefficient $\left(\mathrm{r}_{\mathrm{s}}\right)$ between clients and consultants $=0,47$; the correlation is significant at $5 \%$ level (2-tailed) 
Table 3. Assigned importance levels for different types of clients ${ }^{\text {a }}$

\begin{tabular}{|c|c|c|c|c|c|c|}
\hline \multirow[t]{2}{*}{ Type of client } & \multicolumn{2}{|c|}{$\begin{array}{c}\text { Villa } \\
\text { clients }\end{array}$} & \multicolumn{2}{|c|}{$\begin{array}{l}\text { Apartment } \\
\text { clients }\end{array}$} & \multicolumn{2}{|c|}{$\begin{array}{c}\text { Commercial } \\
\text { building clients }\end{array}$} \\
\hline & RI & Rank & RI & Rank & RI & Rank \\
\hline Price that the contractor firm offers & 0,923 & 1 & 0,975 & 1 & 0,957 & 1 \\
\hline No of years the contractor firm has been doing work in the market & 0,897 & 2 & 0,925 & 2 & 0,936 & 2 \\
\hline The image and identity of the contractor firm in the market & 0,839 & 3 & 0,694 & 5 & 0,864 & 3 \\
\hline Availability of previous experience with similar projects & 0,800 & 5 & 0,806 & 3 & 0,764 & 5 \\
\hline The product's place (if chosen by the contractor) & 0,813 & 4 & 0,538 & 9 & 0,771 & 4 \\
\hline Availability of highly qualified technical staff in the contractor firm & 0,690 & 7 & 0,700 & 4 & 0,657 & 6 \\
\hline References about the contractor & 0,626 & 8 & 0,525 & 10 & 0,643 & 7 \\
\hline Previous records of claims and disputes & 0,587 & 9 & 0,606 & 6 & 0,564 & 12 \\
\hline The contractor firm being a sectoral brand in the market & 0,723 & 6 & 0,431 & 14 & 0,586 & 9 \\
\hline Maximum financial capacity & 0,523 & 13 & 0,581 & 7 & 0,614 & 8 \\
\hline Warranty conditions the contractor firm offers & 0,535 & 12 & 0,575 & 8 & 0,579 & 10 \\
\hline Type of plant and equipment available and suitability of the equipment & 0,548 & 10,5 & 0,519 & 11,5 & 0,571 & 11 \\
\hline Availability of highly qualified managerial staff in the contractor firm & 0,548 & 10,5 & 0,519 & 11,5 & 0,536 & 13 \\
\hline Contractor's familiarity with local suppliers, labour, subcontractors etc & 0,477 & 14 & 0,444 & 13 & 0,486 & 15 \\
\hline Type of project control, monitoring process and cost control & 0,458 & 15 & 0,406 & 15 & 0,507 & 14 \\
\hline Proposed construction method & 0,374 & 17,5 & 0,338 & 16 & 0,407 & 16 \\
\hline Current workload of the contractor & 0,406 & 16 & 0,300 & 18 & 0,364 & 17 \\
\hline The contractor's approach to health and safety on the site & 0,374 & 17,5 & 0,306 & 17 & 0,329 & 18 \\
\hline Average relative index: & 0,619 & & 0,566 & & 0,619 & \\
\hline
\end{tabular}

a Spearman Rank Correlation Coefficient $\left(r_{s}\right)$ between groups 1 and $2=0,81 ; 1$ and $3=0,94 ; 2$ and $3=0,87$; correlation is significant at $1 \%$ significance level for all

Table 4. Assigned importance levels for different types of consultants a

\begin{tabular}{lcccc}
\hline \multirow{2}{*}{ Type of consultant } & \multicolumn{2}{c}{ Engineer } & \multicolumn{2}{c}{ Architect } \\
\cline { 2 - 5 } & RI & Rank & RI & Rank \\
\hline Price that the contractor firm offers & 0,992 & 1 & 0,908 & 1 \\
No of years the contractor firm has been doing work in the market & 0,908 & 3 & 0,892 & 2 \\
The image and identity of the contractor firm in the market & 0,531 & 13 & 0,833 & 5 \\
Availability of previous experience with similar projects & 0,831 & 6 & 0,667 & 9 \\
The product's place if chosen by the contractor & 0,423 & 16 & 0,642 & 10 \\
Availability of highly qualified technical staff in the contractor firm & 0,885 & 4 & 0,875 & 3 \\
References about the contractor & 0,646 & 11 & 0,633 & 11 \\
Previous records of claims and disputes & 0,700 & 10 & 0,675 & 8 \\
The contractor firm being a sectoral brand in the market & 0,369 & 17,5 & 0,567 & 14,5 \\
Maximum financial capacity & 0,923 & 2 & 0,825 & 6 \\
Warranty conditions the contractor firm offers & 0,446 & 15 & 0,492 & 16 \\
Type of plant and equipment available and suitability of the equipment & 0,762 & 7 & 0,717 & 7 \\
Availability of highly qualified managerial staff in the contractor firm & 0,731 & 8 & 0,858 & 4 \\
Contractor's familiarity with local suppliers, labour, subcontractors etc & 0,369 & 17,5 & 0,408 & 18 \\
Type of project control, monitoring process and cost control & 0,715 & 9 & 0,625 & 12 \\
Proposed construction method & 0,838 & 5 & 0,575 & 13 \\
Current workload of the contractor & 0,631 & 12 & 0,567 & 14,5 \\
The contractor's approach to health and safety on the site & 0,454 & 14 & 0,483 & 17 \\
Average relative index: & 0,675 & & 0,680 & \\
\hline
\end{tabular}

${ }^{a}$ Spearman Rank Correlation Coefficient $\left(r_{s}\right)$ between engineers and architects $=0,75$; the correlation is significant at $1 \%$ level 
Table 5. Assigned importance level by the experience of consultant ${ }^{\text {a }}$

\begin{tabular}{|c|c|c|c|c|c|c|}
\hline \multirow[t]{2}{*}{ Experience of consultant in building construction market } & \multicolumn{2}{|c|}{$\begin{array}{c}3-5 \\
\text { Years } \\
\text { (Group 1) } \\
\end{array}$} & \multicolumn{2}{|c|}{$\begin{array}{c}6-10 \\
\text { Years } \\
\text { (Group 2) } \\
\end{array}$} & \multicolumn{2}{|c|}{$\begin{array}{c}>10 \\
\text { Years } \\
(\text { Group 3) } \\
\end{array}$} \\
\hline & RI & Rank & RI & Rank & RI & Rank \\
\hline Price that the contractor firm offers & 0,938 & 1,5 & 0,968 & 1 & 0,947 & 1 \\
\hline No of years the contractor firm has been doing work in the market & 0,938 & 1,5 & 0,937 & 2 & 0,813 & 4 \\
\hline The image and identity of the contractor firm in the market & 0,800 & 7,5 & 0,653 & 11 & 0,573 & 12 \\
\hline Availability of previous experience with similar projects & 0,800 & 7,5 & 0,747 & 6,5 & 0,707 & 9 \\
\hline The product's place (if chosen by the contractor) & 0,563 & 3 & 0,526 & 14 & 0,493 & 13 \\
\hline Availability of highly qualified technical staff in the contractor firm & 0,825 & 5 & 0,905 & 3,5 & 0,907 & 2 \\
\hline References about the contractor & 0,813 & 6 & 0,642 & 12 & 0,453 & 14 \\
\hline Previous records of claims and disputes & 0,600 & 12 & 0,747 & 6,5 & 0,707 & 9 \\
\hline The contractor firm being a sectoral brand in the market & 0,575 & 13 & 0,463 & 16 & 0,347 & 18 \\
\hline Maximum financial capacity & 0,850 & 3 & 0,905 & 3,5 & 0,867 & 3 \\
\hline Warranty conditions the contractor firm offers & 0,538 & 15 & 0,432 & 17 & 0,440 & 15 \\
\hline Type of plant and equipment available and suitability of the equipment & 0,713 & 9 & 0,716 & 8,5 & 0,800 & 5 \\
\hline Availability of highly qualified managerial staff in the contractor firm & 0,838 & 4 & 0,874 & 5 & 0,720 & 8 \\
\hline Contractor's familiarity with local suppliers, labour, subcontractors etc & 0,363 & 18 & 0,411 & 18 & 0,387 & 17 \\
\hline Type of project control, monitoring process and cost control & 0,675 & 10,5 & 0,674 & 10 & 0,667 & 11 \\
\hline Proposed construction method & 0,675 & 10,5 & 0,716 & 8,5 & 0,747 & 6 \\
\hline Current workload of the contractor & 0,463 & 17 & 0,611 & 13 & 0,733 & 7 \\
\hline The contractor's approach to health and safety on the site & 0,488 & 16 & 0,474 & 15 & 0,440 & 15 \\
\hline Average relative index: & 0,692 & & 0,689 & & 0,653 & \\
\hline
\end{tabular}

a Spearman Rank Correlation Coefficient $\left(r_{s}\right)$ between groups 1 and $2=0,751$ and $3=0,60 ; 2$ and $3=0,90$; correlation is significant at $1 \%$ level for all

on the specified factors. Despite differences existing among factor rankings, the S.R.C.C. test showed that a fairly significant correlation exists between two types of consultant groups $\left(r_{s}=0,75\right.$ at $1 \%$ significance level). When the factors are investigated separately in detail, it can easily be seen that both the scores and ranks for various factors change significantly according to the type of consultant. Firstly, engineers seem to place much less emphasis on 'the image and identity of the firm', 'the contractor firm being a sectoral brand' and 'place of the project'. On the other hand, they assigned quite higher rankings to 'previous experience with similar projects', 'maximum financial capacity' and 'proposed construction methods'. Architects pay more attention to the 'availability of managerial staff' while engineers place more emphasis on 'availability of plant and equipment'. Basically, these findings reveal that architects and engineers on building construction market have different perspectives and approaches regarding their needs and expectations on behalf of their clients from the contracting organisations.

Average RI values presented in Table 5 show a moderate decrease in importance assigned to the listed factors by the consultants with more than 10 years of experience on the market. This may be an indication that consultants with less experience lend more overall emphasis on their needs on behalf of their clients. S.R.C.C. test done among three groups showed the existence of varying degrees of correlation. There was an obvious increase in correlation among groups having smaller differences in durations of experience. A strong correlation existed especially between groups 2 and $3\left(r_{s}=0,90\right.$ at $1 \%$ significance level). These findings indicate the approach difference of consultants with varying experience durations.

When the factors and their scores in Table 5 are investigated separately, it is really interesting to observe that consultants with highest experience $(>10$ yrs experience) is placing less importance on 'experience of contractor firms'. Although the 'price offered' was definitely the leading factor in the other two groups, group 1 respondents assigned 'price offered' and 'overall experience' the same importance score and hence the same ranking. Additionally, 'the image and identity of the firm' and 'the contractor firm being a sectoral brand' were assigned significantly decreasing scores with increasing experience in consultants. It seems that new and hence younger consultants have different perspectives regarding the role of image and identity of contracting firms in construction industry. 'References about the contractors' had significant decrease in importance with increasing experience level of consultants as well. 'Availability of managerial staff' seems to be less important for group 3 respondents. On the other hand, 'proposed construction method' 'availability of plant and equipment' were assigned higher scores and rankings by more experienced consultants.

The second part of both questionnaires was related to 'repetitive works concept'. On construction market, 'repetitive works concept' or relationship marketing is another promising approach, which may be easily applied due to the nature of the market. Therefore, finding out the clients' and consultants' approaches to the 'repetitive works concept' separately and comparing them to reveal major differences was the main aim in this section. 
The amount of respondents' desire for continuing to work with the same contractors repetitively in possible future works, was to be determined before starting the discussion of what can actually be done by the contracting organisations to achieve this potential. The results presented in Table 6 show how the client and consultant respondents would react in possible future projects, if they were fully satisfied with the existing or past work of a contractor.

Table 6. Clients' versus consultants' willingness for doing repetitive works

\begin{tabular}{lllll}
\hline & \multicolumn{2}{c}{$\begin{array}{c}\text { Client } \\
\text { respondents }\end{array}$} & \multicolumn{2}{c}{$\begin{array}{c}\text { Consultant } \\
\text { respondents }\end{array}$} \\
\cline { 2 - 5 } Willingness criteria & $\begin{array}{l}\text { Yes } \\
(\%)\end{array}$ & $\begin{array}{l}\text { No } \\
(\%)\end{array}$ & $\begin{array}{l}\text { Yes } \\
(\%)\end{array}$ & $\begin{array}{l}\text { No } \\
(\%)\end{array}$ \\
\hline $\begin{array}{l}\text { Giving priority to } \\
\text { the same contractor during bid } \\
\text { evaluation of future works }\end{array}$ & 93,4 & 6,6 & 82,1 & 17,9 \\
$\begin{array}{l}\text { Willing to give the third party } \\
\text { recommendations in referral } \\
\text { markets }\end{array}$ & 91,2 & 8,8 & 91,0 & 9,0 \\
\hline
\end{tabular}

The results in Table 6 clearly show a very significant potential awaiting the contractor firms in the repetitive works market. It is seen that more than $90 \%$ of all the clients are willing to give priority to their existing or past contractor during bid evaluation of their possible future projects. Considering that repeat business may involve not only one but many possible projects with each client, the potential awaiting should be very clear. Additionally, more than $90 \%$ of the respondents said that they were willing to give the third party recommendations in referral markets. This might also possibly create new markets for the contracting organisations as well. The results obtained from consultants' responses are also promising and more than $80 \%$ of the consultants indicated that they would advise their future clients in giving priority to the contractor that satisfied them in past projects. Although client is the main party who will make the last decision about the contractor selection, it should be kept in mind that consultants usually have high roles regarding this selection process. Also, more than $90 \%$ of the consultants were willing to give third party recommendations in referral markets, which might again create new markets for contractors, considering the possible high role of consultants in giving recommendations.

The next issue for a contracting organization should definitely be how to fully satisfy both clients and consultants in the existing projects to convince them for continuing to do repetitive works with your organization in the future. Both client and consultant respondents were asked to define the importance of a certain list of factors for their full satisfaction. The listed factors were all related to the performance of the contracting firm in the past project(s) with the same client or consultant. The results are presented in Table 7 . The average RI values are very high for both clients and consultants, which reveals the high emphasis assigned to the specified factors by both types of respondents. S.R.C.C. could not show any significant correlation existence among clients and consultants. When the factors are investigated separately, a very significant variation is observed in both scores and the ranks of the factors between the clients and consultants. 'The product's quality and durability', 'finishing within the budget' and 'finishing on time' were found to be very major and important factors for full satisfaction of both groups. Clients selected 'product's quality and durability' while consultants on the other hand selected 'finishing within budget' as the most important factor. In addition to these three factors, there were also

Table 7. Clients' versus consultants' approaches to 'repetitive works concept' a

\begin{tabular}{|c|c|c|c|c|}
\hline \multirow[t]{2}{*}{ Type of respondent } & \multicolumn{2}{|c|}{ Clients } & \multicolumn{2}{|c|}{ Consultants } \\
\hline & RI & Rank & RI & Rank \\
\hline The final product's quality and durability & 0,927 & 1 & 0,892 & 2 \\
\hline The contractor firm finishing the project within the budget scheduled & 0,923 & 2 & 0,912 & 1 \\
\hline The contractor firm finishing the project on time & 0,855 & 3 & 0,876 & 3 \\
\hline $\begin{array}{l}\text { The contractor firm's attitude \&commitment to the client's needs during project } \\
\text { execution }\end{array}$ & 0,752 & 4 & 0,596 & 8 \\
\hline The contractor firm's personnel providing guidance to the client & 0,701 & 5 & 0,384 & 9 \\
\hline $\begin{array}{l}\text { The contractor's success in understanding the client's value system and acting } \\
\text { accordingly }\end{array}$ & 0,673 & 6 & 0,644 & 7 \\
\hline $\begin{array}{l}\text { Responsiveness of the contractor firm } \\
\text { (willingness to help the client and provide prompt service) }\end{array}$ & 0,626 & 7 & 0,692 & 6 \\
\hline $\begin{array}{l}\text { The contractor firm's ability to deal with unanticipated problems during project } \\
\text { execution }\end{array}$ & 0,582 & 8 & 0,712 & 5 \\
\hline The contractor firm working in harmony with the consultant firm & 0,576 & 9 & 0,816 & 4 \\
\hline Average relative index & 0,735 & & 0,725 & \\
\hline
\end{tabular}

${ }^{a}$ Spearman Rank Correlation Coefficient $\left(\mathrm{r}_{\mathrm{s}}\right)$ between clients and consultants $=0,42$; the correlation is significant at $<10 \%$ significance level 
others with significantly high scores, which seem to have important contributions to complete satisfaction well. 'The contractor's harmony with consultant firm' was given a very high importance by the consultants, as expected. On the other hand, clients assigned the lowest importance score to this factor. 'Contractor's guidance' was assigned a very low score by the consultants and ranked $9^{\text {th }}$ while clients ranked the same factor $5^{\text {th }}$.

Obviously, both types of respondents expect much more than the traditional three elements of product quality, finishing on time or within budget for full satisfaction and continuing to do repetitive works. Furthermore, it is found that the expectations of clients and their representatives vary very significantly. In addition to producing high quality work on time and within budget, firms should also understand the clients' and their representatives' needs and expectations from them, develop close relations, deliver high quality service, try to give full satisfaction and then seek repeat business. Also, contracting organisations should combine the expectations of clients and consultant firms and try to formulate strategies that will take both of these parties' demands into account.

Average RI values found for the different types of clients and presented in Table 8 indicate that the importance priority of clients vary widely according to the type of clients. S.R.C.C. test showed varying correlation that existed among the three groups. The correlation was lowest between the rankings of villa and commercial type building clients $\left(r_{s}=0,65\right.$ at $10 \%$ significance level). When the scores are investigated separately, a very sig- nificant variation is observed among different groups. 'Contractor finishing the project within the budget scheduled' was selected as the most important factor by 'apartment' clients while 'product quality and durability' was selected as the most important factor by 'villa' clients. On the other hand, 'commercial building' clients selected the most important factor as 'contractor finishing the project on time'. When the scores and ranks for 'villa' clients are investigated, it can be seen that these clients place more emphasis on project finishing with high quality, according to their needs, expectations and value system, which may be an important finding for building contractors specialising in villa-type building constructions.

Table 9 summarises the results for the two different types of consultants. S.R.C.C. test showed a high correlation that existed among the two parties $\left(r_{s}=0,83\right.$ at $1 \%$ significance level). There were some differences in rankings and hence in approaches of the two groups. While the most important factor for architect respondents was 'final product's quality and durability', engineer respondents identified 'finishing within budget' and 'finishing on time' as more important factors than quality and durability. Another interesting finding was the high difference in scores for the factor 'success in understanding client's value system and acting accordingly'. Architects assigned a much higher score to this specific factor than engineer respondents. On the other hand, engineers placed more emphasis on 'responsiveness of the contractor firm' and 'ability to deal with unanticipated problems' than architects did. As a result, these findings re-

Table 8. Assigned importance level for different types of clients a

\begin{tabular}{|c|c|c|c|c|c|c|}
\hline \multirow[t]{2}{*}{ Type of client } & \multicolumn{2}{|c|}{$\begin{array}{l}\text { Villa } \\
\text { clients }\end{array}$} & \multicolumn{2}{|c|}{$\begin{array}{l}\text { Apartment } \\
\text { clients }\end{array}$} & \multicolumn{2}{|c|}{$\begin{array}{l}\text { Commercial } \\
\text { building } \\
\text { clients }\end{array}$} \\
\hline & RI & Rank & RI & Rank & RI & Rank \\
\hline The final product's quality and durability & 0,974 & 1 & 0,881 & 2 & 0,929 & 3 \\
\hline The contractor firm finishing the project within the budget scheduled & 0,877 & 2 & 0,944 & 1 & 0,950 & 2 \\
\hline The contractor firm finishing the project on time & 0,755 & 6 & 0,838 & 3 & 0,986 & 1 \\
\hline $\begin{array}{l}\text { The contractor firm's attitude \& commitment to the client's needs during } \\
\text { project execution }\end{array}$ & 0,852 & 4 & 0,675 & 4 & 0,729 & 4 \\
\hline The contractor firm's personnel providing guidance to the client & 0,858 & 3 & 0,581 & 5 & 0,664 & 5,5 \\
\hline $\begin{array}{l}\text { The contractor's success in understanding the client's value system and } \\
\text { acting accordingly }\end{array}$ & 0,832 & 5 & 0,525 & 7 & 0,664 & 5,5 \\
\hline $\begin{array}{l}\text { Responsiveness of the contractor firm } \\
\text { (willingness to help the client and provide prompt service) }\end{array}$ & 0,716 & 7 & 0,563 & 6 & 0,600 & 8 \\
\hline $\begin{array}{l}\text { The contractor firm's ability to deal with unanticipated problems during } \\
\text { project execution }\end{array}$ & 0,652 & 9 & 0,488 & 9 & 0,614 & 7 \\
\hline The contractor firm working in harmony with the consultant firm & 0,658 & 8 & 0,513 & 8 & 0,557 & 9 \\
\hline Average relative index & 0,797 & & 0,668 & & 0,744 & \\
\hline
\end{tabular}

${ }^{a}$ Spearman Rank Correlation Coefficient $\left(r_{s}\right)$ between groups 1 and $2=0,83 ; 1$ and $3=0,65 ; 2$ and $3=0,85$; correlation is significant at $1 \%, 10 \%$ and $1 \%$ levels respectively 
Table 9. Assigned importance level for different types of consultants a

\begin{tabular}{|c|c|c|c|c|}
\hline \multirow[t]{2}{*}{ Type of consultant } & \multicolumn{2}{|c|}{ Engineers } & \multicolumn{2}{|c|}{ Architects } \\
\hline & RI & Rank & RI & Rank \\
\hline The final product's quality and durability & 0,838 & 3,5 & 0,950 & 1 \\
\hline The contractor firm finishing the project within the budget scheduled & 0,969 & 1 & 0,850 & 2 \\
\hline The contractor firm finishing the project on time & 0,938 & 2 & 0,808 & 3 \\
\hline $\begin{array}{l}\text { The contractor firm's attitude \& commitment to the client's needs during project } \\
\text { execution }\end{array}$ & 0,569 & 7 & 0,625 & 8 \\
\hline The contractor firm's personnel providing guidance to the client & 0,369 & 9 & 0,400 & 9 \\
\hline $\begin{array}{l}\text { The contractor's success in understanding the client's value system and acting } \\
\text { accordingly }\end{array}$ & 0,554 & 8 & 0,742 & 5 \\
\hline $\begin{array}{l}\text { Responsiveness of the contractor firm } \\
\text { (willingness to help the client and provide a prompt service) }\end{array}$ & 0,723 & 6 & 0,658 & 7 \\
\hline $\begin{array}{l}\text { The contractor firm's ability to deal with unanticipated problems during project } \\
\text { execution }\end{array}$ & 0,746 & 5 & 0,675 & 6 \\
\hline The contractor firm working in harmony with the consultant firm & 0,838 & 3,5 & 0,792 & 4 \\
\hline Average relative index & 0,727 & & 0,722 & \\
\hline
\end{tabular}

a Spearman Rank Correlation Coefficient $\left(r_{s}\right)$ between engineers and architects $=0,83$; the correlation is significant at $1 \%$ level

veal that engineers' and architects' perspectives and expectations from contracting firms they worked with in past projects vary as well.

\section{Conclusions and recommendations}

The contracting organisations in construction industry have been focusing on three main criteria for satisfying clients. These are completing the work with a specified quality, within budget and on time. However, the results of this study revealed that clients have much more expectations and needs for achieving full satisfaction.

The results of this study also reveal that the consultants' needs and expectations on behalf of their clients vary very significantly from the clients themselves. Considering the fact that consultants are experts of the specified issue and clients almost always have no background or even knowledge in construction, this finding may be actually expected. Consultants have very significant roles during contractor qualification and selection processes. Therefore, if the strategies of the contracting organisations are based on input, which does not take consultant's perspective into consideration, they may not serve the purpose completely. Hence, the complete results of this study will actually guide the related contractor firms in formulating correct strategies.

Moreover, the responding clients belonging to different subgroups have assigned significantly different importance ratings to the listed criteria. Hence, the study's results suggest that contracting organisations may benefit from market segmentation and serve the clients in a more effective manner in the chosen market segments. Additionally, the perspectives of different types of consultants were found to be rather different regarding the expectations from contracting organisations on behalf of their clients. It seems that architects and engi- neers have different expectations from contracting organisations, which will be another important fact to be taken into account by the contractors. Experience of consultants was another control variable tested and interesting results were found showing the different approaches of consultants even with varying durations of experience on building construction market.

In the second part of the study, the responding clients' and consultants' desires to continue doing possible repetitive works with the same contractors were investigated and high willingness of both parties were found. This finding was another indication of the fact that relationship marketing is suitable to be applied in the construction industry. It is also obvious from the findings that the relevant elements of complete satisfaction for private building construction clients do not only include the three main criteria of finishing on time, within budget and with a specified quality. Furthermore, the consultants' expectations, which are very different from the clients, make this issue even more complicated. It seems that contracting organisations should try to achieve the potential available in 'repetitive works' sector by taking into account various criteria, which are all identified and discussed within this study.

To survive in the intense competition existing in today's construction markets, contractors need to fully satisfy clients and their representatives. This is possible only if the expectations of the clients and consultants are identified in a correct and complete manner. This study provided a complete framework for achieving that purpose.

This study included respondents from private building construction market only. Considering the variations existing in different sectors of the construction markets, this study can be extended for different types of sectors, which will allow one to make comparisons among them. 


\section{References}

1. Maloney, W. M. Construction product/service and customer satisfaction. Journal of Construction Engineering and Management, Vol 128, No 6, 2002, p. 522-529.

2. Torbica, Z. M. and Stroh, R. C. Customer satisfaction in home building. Journal of Construction Engineering and Management, Vol 127, No 1, 2001, p. 82-86.

3. Al-Momani, A. H. Examining service quality within construction processes. Technovation, Vol 20, No 11, 2000, p. $643-651$.

4. Smyth, H. Partnering: Practical problems and conceptual limits to relationship marketing. International Journal for Construction Marketing, Vol 2, No 1, 2000, p. 1-10.

5. Hatush, Z. and Skitmore, M. Criteria for contractor selection. Construction Management and Economics, Vol 15, No 1, 1997, p. 19-38.

6. Holt, G. D.; Olomolaiye, P. O.; Harris, F. C. Evaluating prequalification criteria in contractor selection. Building and Environment, Vol 29, No 4, 1994, p. 437-448.

7. Hatush, Z. and Skitmore, M. Assessment and evaluation of contractor data against client goals using PERT approach. Construction Management and Economics, Vol 15, No 4, 1997, p. 327-340.

8. Hatush, Z. and Skitmore, M. Contractor selection using multi-criteria utility theory: An additive model. Building and Environment, Vol 33, No 2, 1998, p. 105-115.
9. Jennings, P. and Holt, G. D. Prequalification and multicriteria selection: a measure of contractors' opinions. Construction Management and Economics, Vol 16, No 6, 1998, p. 651-660.

10. Ng, S. T. and Skitmore, M. Client and consultant perspectives of prequalification criteria. Building and Environment, Vol 34, No 5, 1999, p. 607-621.

11. Alsugair, A. M. Framework for evaluating bids of construction contractors. Journal of Management in Engineering, Vol 15, No 2, 1999, p. 72-78.

12. Ng, S. T.; Skitmore, M.; Smith, N. J. Decision-makers' perceptions in the formulation of prequalification criteria. Engineering Construction and Architectural Management, Vol 6, No 2, 1999, p. 155-165.

13. Wong, C. H.; Holt, G. D.; Cooper, P. A. Lowest price or value? Investigation of UK construction clients' tender selection process. Construction Management and Economics, Vol 18, No 7, 2000, p. 767-774.

14. Palaneeswaran, E. and Kumaraswamy, M. Recent advances and proposed improvements in contractor prequalification methodologies. Building and Environment, Vol 36, No 1, 2001, p. 73-87.

15. Shash, A. Factors considered in tendering by top UK contractors. Construction Management and Economics, Vol 11, No 2, 1993, p. 111-118.

16. Kometa, S. T.; Olomolaiye, P. O.; Harris, F. C. Attributes of UK construction clients influencing project consultants' performance. Constuction Management and Economics, Vol 12, No 5, 1994, p. 433-443.

\section{SKIRTINGAS KLIENTŲ IR KONSULTANTŲ POŽIŪRIS İ RANGOVO KVALIFIKACIJĄ IR ATRANKĄ}

\section{Egemen, A. N. Mohamed}

Santrauka

Šiandien užsakovai tampa svarbiausia grupe beveik visose pramonės šakose. Tačiau statybos pramonė unikali tuo, kad joje svarbiu asmeniu laikomas dar ir konsultantas, kuris samdomas kaip užsakovo atstovas. Pateikti 91 kliento ir 50 užsakovų apklausos rezultatai, kurie parodè, kaip skiriasi klientų ir užsakovų lūkesčiai dèl rangovų kvalifikacijos ir atrankos. Tyrimas parodè, kad konsultantų reikalavimai rangovams labai skiriasi nuo užsakovo reikalavimų, be to, skirtingi konsultantai ir užsakovai kelia skirtingus reikalavimus rangovams. Tyrimas parodè, kad užsakovai ir klientai yra linkę tęsti bendradarbiavimą su tuo pačiu rangovu tvirtindami, kad yra patenkinti jo ankstesniu darbu. Nustatyti kriterijai, kurių atitikimas lemia užsakovo ir(arba) konsultanto pasirinkimą ir galimybę ateityje laimèti konkursus. Pateikta sistema leidžia konkursuose dalyvaujančioms įmonėms suvokti ir palyginti užsakovų ir konsultantų reikalavimus rangovo atrankos metu. Konkursuose dalyvaujančios įmonès gali naudoti tyrimo rezultatus tam, kad suvoktų užsakovo poreikius, atitinkamai suformuluotų ir pritaikytų savo strategijas.

Raktažodžiai: rangovo kvalifikacija, rangovo atranka, užsakovo lūkesčiai, konsultanto lūkesčiai, užsakovo poreikių patenkinimas, pasikartojantys darbai.

Mehmedali EGEMEN. MSc, PhD student of Construction Management in the Dept of Civil Engineering at Eastern Mediterranean University. BS in Civil Engineering and MS in Construction Management from Eastern Mediterranean University, North Cyprus. Research and teaching assistant for 6 years and instructor for 1 year in Eastern Mediterranean University. Main research interests: optimization, costing in construction, knowledge based systems, clients' satisfaction, value management, construction marketing and bidding strategies.

Abdulrezak N. MOHAMED. Assistant Prof of Construction Management in the Dept of Civil Engineering at Eastern Mediterranean University. BS in Civil Engineering from Eastern Mediterranean University, North Cyprus. MS in Construction Management of the Middle East Technical University, Ankara (Turkey) and PhD in Construction Management from Eastern Mediterranean University, North Cyprus. Vice-chairman of the Dept of Civil Engineering and Director of Construction Management Research and Practice Centre (CMRPC). Main research interests: construction planning and scheduling, TQM in construction, knowledge-based systems, bidding and estimating, construction productivity and construction marketing. 